FORUM 


\title{
Anthropology after the crisis
}

\author{
James G. Carrier
}

\begin{abstract}
Recently anthropology has experienced an intellectual crisis of confidence, a sense that the discipline has lost its way, and an institutional crisis, a loss of resources following the financial crisis. Together, these crises provide a perspective that helps us to make sense of what preceded them. This article argues that both crises are signs of the failure of the neoliberalism that rose to prominence in the 1980s, both as a foundation for public policy and as an important, though unrecognized, influence on elements in anthropological thought. It focuses on that influence. It does so by describing some of the changes in anthropological orientation since the 1980s. Prime among these are the loss of disciplinary authority, the solidification of the focus on culture at the expense of a focus on society, and the rejection of systemic theories of social and cultural order. It is argued that, together, these changes have left anthropologists with no critical perspective on the world, just as the ascendance of neoclassical economics left economists with no such critical perspective.
\end{abstract}

Keywords: crisis, culture, neoliberalism, postmodernism

"The owl of Minerva spreads its wings only with the falling of the dusk".

-Hegel.

Anthropology has been experiencing two crises. One is internal to the discipline, concern about its state and future, signaled by the theme of the 2009 conference of the American Anthropological Association (AAA), "The End/s of Anthropology," and by works with titles like The End of Anthropology? (Jebens and Kohl 2011). The other is external to the discipline, the economic crisis that began in 2008. These two crises are linked, as both are reflections of the inadequacies of one of the important ideologies of the closing decades of the twentieth century, "the free market" (Carrier 1997), which in its ascendance commonly has been called "neoliberalism" (Harvey 2005).

The influence of that ideology started to expand rapidly in the 1970s, when Keynesian political economy died and the neoclassical economics associated with the University of Chicago emerged in its place. Its triumphal moment was the fall of the Berlin Wall in 1989, seen as a victory for free market capitalism that signaled The End of History (Fukuyama 1992). The triumphalists told us that the fall of the 
Wall was a memorial to popular rejection of systems that denied the self-evident virtues of liberal economy, systems that marked out The Road to Serfdom (Hayek 1944). With that rejection, we were told, we entered the best of all possible worlds, free of constraint and, finally, globally, able to make our own, individual choices in the free market, the foundation of a free society. Status and ascription were dead, authority and system were denied, freedom and prosperity beckoned.

\section{Neoliberalism and anthropology}

I said that the two crises are linked to each other and to the inadequacies of neoliberalism. The economic crisis made it apparent that it was inadequate as a basis of economic policy. Even Alan Greenspan, long the revered Chairman of the US Federal Reserve and strong advocate of free markets, said that things had not turned out as he expected, and expressed his "shocked disbelief" at the failures that brought about the crisis (Andrews 2008). This failure of neoliberalism affected higher education, and hence anthropology.

Policies adopted in many countries to respond to that crisis meant that universities confronted governments increasingly anxious to cut spending, especially in areas that were not seen as contributing to the national economy in the face of international competition. Such policies could lead to continued support for programs in engineering and the natural sciences, and to a slighting of the humanities and social sciences, including anthropology. As well, potential students increasingly were encouraged to assess their education in terms of the jobs that it would allow them to get (e.g., Boffey 2011), putting disciplines like anthropology under further pressure. Together, budget cuts and fears about future enrollments encouraged unhappiness, if not despair, in the discipline.

Neoliberal ideology had, of course, been affecting higher education, and with it anthropology, well before the crisis. Many of these effects are familiar under the name of "audit culture" (M. Strathern 2000), and I will mention only one of them, and only briefly: a change in the concern shown for the productivity of academics, particularly scholarly publications. Publications had long been important for academics, but the growth of audit culture brought new ways of assessing them. Most striking was an increasing invocation of what were presented as neutral and objective measures of quality, such as the number of times a work is cited by others or the frequency of citation to the periodical in which it appears ("impact factor"). With this, those responsible for assessing an academic's publications do not have to read, much less think about, any of them. Instead, they can base their assessment on what the pertinent public thinks about that work, measured by the relative frequency with which it or the journal in which it appeared is cited.

The result has been a tendency to a more uniform intellectual landscape. Like the market measure of price, the measure of impact is indifferent to qualitative difference, in this case differences between periodicals, such as those devoted to different regional or national anthropological traditions, to specific ethnographic regions, or to specialist topics. In a kind of academic globalization, then, qualitative differences tend to be overwhelmed by the desire of academics, and the demands of those who assess them, for high impact scores, disproportionately associated with a small number of periodicals published in the US (e.g., Science Watch 2011). As a result, academics are induced to make their writing resemble the American anthropology of those journals. For a discipline that values diversity, this appears unfortunate; for academics trained in other anthropological traditions, not to mention those whose native language is not English, it is a disadvantage.

I said that anthropology's crises are linked to neoliberalism and its inadequacies. Thus far I have described briefly some of the more familiar of those links, as the nature and shortcomings of neoliberalism have affected the discipline's institutional home, higher education. Given those effects, it is understandable that the theme of the 2009 AAA conference was "The End/s of Anthropology." 


\section{Neoliberalism in anthropology}

That worry about the end/s of anthropology was sparked as well by the second crisis that I mentioned, an intellectual exhaustion and sense that the old ways of doing things no longer made much sense. As George Marcus (2008: 2) put it, the discipline is "in suspension," with "no new ideas and none on the horizon" and with "no indication that its traditional stock of knowledge shows any signs of revitalization"; though by the time he said those words, of course, the main ideas and stock of knowledge at issue were those of the postmodernism that he helped so much to bring about.

Certainly not all anthropologists were wedded to those ideas, and so not all saw themselves and their work as being in suspension. The neoliberal Washington Consensus began looking tattered by 2000 , which helps account for a minor boom in economic anthropology; the failure of the triumphalists' promised world to appear in the countries of the former Soviet bloc helps account for a similar boom in anthropological work on the region. And, of course, there were anthropologists who continued to pursue the ideas of scholars like Sidney Mintz (e.g., 1985) and Eric Wolf (e.g., 1982). Exhaustion and crisis, then, were hardly universal. However, these sorts of works increasingly appeared as heterodox or specialist subparts of the discipline. The view of those who occupied the commanding heights of anthropology was expressed by the theme of the 2009 AAA meeting, an expression that marked theirs as the dominant stream within the discipline. That stream is my concern here.

The crisis experienced by those in that dominant stream also reflects the inadequacies of neoliberalism, for part of the reason why the old ways of doing things no longer made much sense was that important elements of them reflected neoliberal ascendancy. It may be contentious to see those old ways as reflecting neoliberalism, which many anthropologists saw as alien, even inimical, to their understanding of the world, their discipline, and their intellectual endeavors. However, aspects of that dominant stream resemble aspects of neoliberal thought. Identifying them provides a perspective on the recent history of anthropology that can help us, located as we are at the falling of the dusk, to make sense of what the commanding heights of the discipline had become, and so help us to think about what we might want anthropology to become in the future.

My point that we can see the influence of neoliberalism in that mainstream anthropology is a recognition that the elements of neoliberal ideology were protean. The authority that the ideology denied, the ascription that it rejected, and the system that it abolished took different forms in different settings. One setting was American anthropology. There, the presidency of Ronald Reagan brought the first wave of the postmodernist movement, which was signaled by Clifford and Marcus's collection Writing Culture (1986) and which spread from the United States to the Britain of Margaret Thatcher, and to anthropology more generally, evolving as it did so. With that movement, disciplinary authority was denied, an illegitimate distortion of the lives of those we studied serving little purpose beyond improving anthropologists' job prospects. With that, status was rejected, as the categories and classes of people and relationships that were the scholarly apparatus of conventional anthropology had to yield to the lived experiences of those who were our interlocutors and collaborators. With that, system was abolished, the stuff of grand narratives that blinded us to people's lives and agency.

Together, these aspects of postmodernism marked a changed understanding of the proper relationship between anthropologists and the people they studied, one that echoed the ascendant neoliberal understanding of the proper relationship between governments and the countries they governed, especially in the crucial area of the economy. Since the Great Depression, many of those governments had sought to apply Keynesian models to what they knew of their countries' economies, and formulate policies that would improve public welfare. However, in the tales told by the triumphant neoliberals, Keynesianism had shown itself to be a failure in the 
1970s because it could not deal with the "stagflation," the combination of economic stagnation and inflation, that began in many Western countries in 1973. For those neoliberals, that failure was no warrant for trying to improve Keynesian models, simply because those models were macroeconomic: summary understandings of the processes and institutions that make up a country's economy. In contrast, the neoliberals embraced Hayek's (1944: 204) advice that governments should resist "the craving for intelligibility" about how the economy operates and why.

That failure of Keynesianism made it clear to these triumphalists that the proper role of governments was letting people judge things for themselves, which they did in their daily transactions in free markets. This view reflected the belief that markets are not only efficient, but also rational (cf. Fox 2009). In turn, this belief rested on the assumption that the market is the aggregate of the judgments that individuals freely make concerning their own welfare, expressed in their decision to spend their money one way rather than another, and on the assumption that in their aggregate judgments these individuals see things clearly. These are, of course, the assumptions that justify treating the frequency of citations as the measure of the worth of a piece of scholarly writing: when they cite a work, academics freely make judgments about the worth of that work, expressed in their decision to cite one publication rather than another, and in their aggregate judgments they see things clearly.

In this neoliberal view, governments should do no more than let the markets run, and perhaps assure that they run freely. In a sense, then, governments have, and should have, no authority over what goes on in the economy. Indeed, they should not think about it, in the way of the discredited Keynesians and their macroeconomic approach. Rather, they should only monitor and, perhaps, respond to it, and carry out the moral and political task of facilitating the extension of market transactions and market rationality by removing policies and practices that hinder the expression of this natural human proclivity.
Much of this was echoed in anthropology, which also faced challenges in the 1970s. For instance, we were told that the discipline was inevitably shaped by colonialism. Perhaps the most cogent statement of this view came from Talal Asad (1973), while Ranajit Guha's Subaltern Studies (1982) made a similar argument in a somewhat different way. That period also saw the publication of Said's Orientalism (1978). While he was concerned with Oriental studies, many anthropologists applied his argument to themselves, seeing ways in which those within the discipline, inflected with colonialism and its attendant ideologies, construed what they saw when they were in the field in essentialist and alien terms (e.g., Fabian 1983).

These challenges were the background for the emergence of postmodernism, and for many it led to a stance that was the same as the neoliberals': do not look for a better grand narrative, a better encompassing model or theory, for all such are, like those Keynesian models, radically flawed. Instead, the anthropologist's job is the same as the government's: only to observe and record, and perhaps help assure that things run smoothly by carrying out the moral and political task of presenting the lives of the marginalized in the hope that this will weaken policies and practices that hinder the expression of natural human diversity.

With this, those postmodernist critics kicked away one of the two legs on which, said RadcliffeBrown (1952), anthropology stood. One of those legs is the idiographic, which he called "ethnography," the description of what the researcher observes in anthropological terms. The other is the nomothetic, which he called "comparative sociology," the development of reasonably valid generalizations about, and understandings of, social life in a range of societies. For the critics, it was necessary to pursue the ethnography and eschew the comparative sociology.

The decades between World War II and Writing Culture were awash with theoretical approaches that presumed an order or structure, a system, a Society or Culture, in the same way that the Keynesians presumed an Economy. The structural functionalism that was important in 
Britain announced that in its very name. The same was true in the United States, for instance in work that identified and described Patterns of Culture (Benedict 1934). The Lévi-Straussian structuralism of the 1960s was notorious in this regard, and for many the Marxist anthropology that challenged it, especially the work of the structural Marxists (e.g., Althusser and Balibar 1970), was not much different.

The critics said that the power that these models assigned to Society or Culture was too great. This was the gravamen of an influential assessment that appeared at about the same time as Writing Culture, by Sherry Ortner (1984), concerned with the dominant theoretical schools of the 1970s. She argued that the attention these schools paid to structure needed to be complemented by greater attention to people and their lives. As she (ibid: 148) put it, the important question is "the relationship(s) that obtain between human action, on the one hand, and some global entity which we may call 'the system,' on the other." Without that attention, we run the risk of seeing the world without people, at least without people who have the capacity to think and act.

Ortner's criticism was not, of course, novel in the social sciences. Twenty years previously an American sociologist, Dennis Wrong (1962), argued against his discipline's structural functionalism. He said that it contained an "oversocialized conception of man," in which people were merely enacting the roles defined by their statuses. Just a few years before Ortner, another American sociologist, Jeffrey Alexander (1982: 98), raised the same concern in a somewhat different way. He asked, "How [can] sociological theories which do accept the sui generis collective character of social arrangements ... retain a conception of individual freedom and voluntarism?" The change in terminology is interesting. While Wrong was concerned with the motives of human action that might lie outside of the social structure, Alexander was concerned with "freedom," which is something rather different.

Ortner's criticism, like the more widespread sentiments that she expressed, was taken to point in two different, but related, directions. In one, anthropologists argued that the structuralist, synchronic attention to order diverted attention from what is at least as ubiquitous, diachronic change. The debates about the relationship between order and change became encapsulated in the label "structure versus process," and one of the most articulate attempts to deal with that relationship was Marshall Sahlins's (1985) analysis of the arrival of Captain Cook in Hawaii, his departure, his unexpected return, and his subsequent death there. The vision that Sahlins offered was of a society that was jarred from its course by the intrusion of contingent events, themselves interpreted in terms of the society's cultural frame: the structure of the conjuncture.

The second direction in which Ortner's criticism was taken to point reflected the argument that attention to structure diverted attention from what is more basic, human action, and that it is necessary to consider the ways that people's activities do or do not conform to the dictates of the structure, and hence do or do not reproduce it. Debates about this question became encapsulated in the label "structure versus agency." Probably the best-known attempt to deal with this dichotomy is the concept of habitus, developed by one of the "practice theorists" that Ortner lauded, Pierre Bourdieu (1977), in Outline of a Theory of Practice. He argued that people acquire certain predispositions over the course of their lives. These predispositions, this habitus, lead them to perceive and act in the world in particular ways, which, in Bourdieu's somewhat pessimistic view, tends to reproduce the social order and their place in it. Or, as he put it, "Le mort saisit le vif" (1980).

The debates about structure versus process and structure versus agency were not resolved; indeed, they could not be resolved, because they reflected fundamental differences in orientation. Instead, they were abandoned. In the process, Ortner's injunction that we should investigate the relationship between people's actions and the social or cultural structure got turned into a rejection of structure, poststructuralism. For many, this led to an embrace of what came to be called "everyday life" and "lived experience," which is what Bourdieu (e.g., 1977: 3-4) 
said was inadequate as a foundation for understanding social life.

Thus it was that the older concern with the nature of society and culture in general, the furthermost reaches of Radcliffe-Brown's comparative sociology, was rejected. The Durkheimian vision laid out in The Division of Labour ([1893] 1984), of society as an emergent entity with properties of its own that are in dialectical relationship with the thoughts and actions of the people within it, was denied. Moreover, it was denied in such a way that the very idea of society and culture associated with a particular set of people in a particular place and time was tainted: its boundaries were too porous, and it contained too many disagreements and divergent perspectives, to allow anyone to speak of such things (Gupta and Ferguson 1997). In this rejection, many in the discipline echoed the triumphalist economists' rejection of the Keynesian concern with systems. It seemed that Margaret Thatcher and the neoliberals were right: there was no such thing as society; and one of those not party to this change within the discipline noted "a distressing pleasure to find such a coincidence between neo-conservative [i.e., neoliberal] and post-modernist thought" (Roseberry 1997: 257). Any apparent attributes of societies or cultures, like any apparent attributes of markets (or, to hark back to audit culture, like any apparent attributes of scholarly work), are an epiphenomenon reducible to a sort of arithmetic sum of individuals and the decisions they make.

\section{Neoliberal anthropology}

Many anthropologists, then, rejected the older concern for social or cultural systems, instead following the neoclassical economists in their privileging of people's individual decisions and actions. This rejection did not happen all at once and all in the same way in all parts of the discipline, and, as I noted, not all anthropologists were party to it. Regardless of how this rejection occurred, however, it had consequences for what the anthropologists who occupied those commanding heights, and those who sought to emulate them, commonly investigated, the arguments they made, and the ways they went about their business. Here I will sketch one of the more obvious forms it took, changes in the importance of The Native's Point of View, long central within the discipline.

One should not be misled by this longevity. As the intellectual context of the concern with that Point of View changed in the closing decades of the twentieth century, so did its content and significance. To begin to show this, I invoke that founding figure, Malinowski. In Argonauts of the Western Pacific (1922), he reported the results of his attention to the view of the natives of the island of Kiriwina. His attention, however, was not that of the stereotypical folklorist, interested in collecting facts about the customs and beliefs of a particular set of people.

Rather, Malinowski used what he learned of how Kiriwina people see their world to discern and make sense of regularities and structures, such as the kula ring itself, to which Kiriwinans probably were indifferent and of which they may well have been ignorant. Rather, whether or not they were indifferent and ignorant is immaterial, for Malinowski was motivated by the concerns and perspectives of his discipline, not of Kiriwinans. In addition, he used what he learned from the Kiriwinan Point of View to address broader questions about how people transact things; not just Kiriwina people or Massim people or even Melanesian people, but people in general (1921). In this, Maliowski's concern with The Native's Point of View was no different from that of Evans-Pritchard's (1940) concern about The Nuer, Michael Taussig's (1977) concern about people in the Cauca Valley, or Marilyn Strathern's (1988) concern about Melanesians. For all of them, attention to that Point of View was the vehicle for addressing questions that were important in the discipline, and indeed more generally, but that may well have been invisible to The Natives. Such anthropologists resembled the Keynesians, concerned with reflecting on questions that may well have been invisible to a different set of Natives in their daily economic lives. 
In contrast, the closing decades of the twentieth century saw an increasing interest among anthropologists with The Native's Point of View as an end in itself. For some, this was a perspective to be described; some others took a more radical position. In his address to the fifth decennial meeting of the Association of Social Anthropologists of the UK and Commonwealth (ASA), Eduardo Viveiros de Castro (2003) said it was a perspective that anthropologists should don, not with Malinowski's goal of understanding why people act as they do, but instead with the goal of understanding what the world is. That changing interest did not reflect only the spread of postmodernism. In addition, it reflected the cultural turn in American anthropology that fed into and facilitated the emergence, development, and spread of postmodernism. That turn was associated especially with the work of Clifford Geertz, and its most influential expression was his The Interpretation of Cultures (1973).

In the opening pages of that book, Geertz argued for an anthropology that seeks to understand how people think about things. This is no surprising stance, as Geertz (1973: 5) indicated when he said that he believes, "with Weber, that man is an animal suspended in webs of significance." The aspects of how people think that concerned Geertz are not surprising, either. They are the aspects that do not make sense when we encounter them; or, in his words, "social expressions on their surface enigmatical" (ibid: 5). While the thinking at issue is fairly straightforward, the understanding is less so. That is because Geertz's approach is "essentially a semiotic one" (ibid: 5), concerned with meaning and meaning alone. He stresses this point at the end of the most popular chapter in his book, "Deep Play: Notes on the Balinese Cockfight." There, he contrasts the semiotic approach favorably with the sociological ("functionalism") and the psychological ("psychologism"). Unlike those approaches, his semiotic approach allows "the possibility for an analysis which attends to ... [the] substance [of symbolic expressions like the cock fight] rather than reductive formulas professing to account for them" (ibid.: 453). Like Hayek, then, Geertz urged us to ignore "the craving for intelligibility," or at least the intelligibility that comes from accounting for things.

The functionalism that Geertz dismissed works, of course, both ways. When he rejected functionalist approaches, Geertz was not only rejecting efforts to uncover factors external to those symbolic expressions that might shape them; he was also rejecting efforts to uncover external factors that those expressions might shape. In rejecting functionalism, then, Geertz rejected a search for both causes and consequences. The result is that culture, meaning, what people think, stands on its own, waiting to be elucidated by anthropologists. The Weber that Geertz invoked, then, turns out to be the one who described the worldview of ascetic Protestants, the webs of significance in which they were suspended, but not the one who traced its influence on the emergence of rational capitalism, much less the one who contemplated the iron cage (Weber [1904-1905] 1958).

I said that the cultural turn prefigured and facilitated aspects of postmodernism. That is because Geertz's stress on interpretation and his rejection of the search for cause and consequence restricted anthropology to RadcliffeBrown's ethnography and debarred comparative sociology. Moreover, Geertz's ethnography resembled American anthropology more generally in that it was focused resolutely on cultural meanings. The extent of the spread of this focus over the ensuing three decades is apparent in the words of a Brazilian anthropologist, Viveiros de Castro, directed to a group predominantly of British anthropologists, in the above-mentioned address to the ASA decennial: "[T]he 'anthropologist' is someone who discourses on the discourses of a 'native"' (2003). More purely social aspects of people's lives, especially those that are not objects of people's cultural attention and elaboration, played little role in the world that anthropologists contemplated.

Although Geertz rejected reductive formulas, he did not mean that cultural phenomena were simply to be recorded and reported in their fullness. Rather, the job of anthropologists is to make sense of them, but in a particular way. 
This is the sense that comes with recognizing a pattern, as, for example, one recognizes that those four lines are "a square," which is different from the reductive task of explaining how those lines came to be aligned as they are and where they are. In a discussion of ethnographic methodology, Geertz (1974) made it clear that the interpretation of culture arises from the continual cycling back and forth between the terms and expressions of the people being studied (the emic, the insider's view, the experience-near) and the general terms provided by anthropology (the etic, the analyst's view, the experiencedistant). The result is an interpretation of what a set of people think that "is neither imprisoned within their mental horizons, an ethnography of witchcraft as written by a witch, nor systematically deaf to the distinctive tonalities of their existence, an ethnography of witchcraft as written by a geometer" (ibid.: 29).

This sort of making sense entails the use of analytical constructs and terminology, such as the consideration of personhood that Geertz used to illustrate his discussion of ethnographic methodology. His use of such terms does not, however, mean that Geertz was addressing a theory of personhood, its nature, causes, and consequences. As I have explained, he restricted himself only to elucidating those enigmatical expressions. Anthropologists who have rejected metanarrative and grand theory also occasionally use terms that are analytical, "neoliberalism," "agency," and "mentality" being perhaps the most obvious ones. Frequently, however, these terms are, like Geertz's, convenient anthropological labels for identifying things. They may have emerged from particular theoretical arguments, but their use need not mark a theoretical concern or orientation.

While anthropologists occasionally seem to see science as an authoritative forcing of the world into a set of preexisting categories, it is more subtle than that. Rather, it is the sustained effort to bring experience of the world into contact with theories and analytical frames with the purpose of improving both the knowledge of the world and the theories. Geertz's preferred anthropology, then, was not science. The disci- plinary terms he deployed in his discussion of ethnographic methodology were used to label things, not to address analytical issues, and he dismissed attention to causes and consequences of the cultural expressions that concerned him.

As Geertz's influence spread, a growing number of anthropologists became concerned with how well we grasp The Native's Point of View. This concern with what people think solidified the cultural side of anthropology over the social side, marked by Clifford and Marcus calling their volume Writing Culture, not Writing Society. It also elevated the insider, the native, bred and born in that point of view, over the outsider, the analyst, for whom it is always, at best, a second language. This is another of the questions important in anthropology that were important as well in other social sciences. For instance, it had emerged clearly in what was becoming known as "Black studies" in the United States (see, e.g., Merton 1972).

This elevation of the insider was apparent in interest in a variety of ethnohistory concerned with how a set of people see their own past (e.g., Gewertz and Schieffelin 1985). Such work resembled the interest emerging among South Asianists with the subaltern view and, whatever its scholarly merits, it lent support to the assumption, or perhaps the fear, that regardless of what the ethnographer may have learned from burrowing in the archives, that knowledge was flawed, was "[n]ot the way it really was" (Neumann 1989). This tension between insiders and outsiders achieved striking, if complex, expression in the debate between Marshall Sahlins and Gananath Obeyesekere that followed Sahlins's work on Captain Cook and Hawaii mentioned above (Sahlins 1985, followed by Obeyesekere 1992, followed by Sahlins 1995).

For Geertz and the ethnohistorians, and for Sahlins if not for Obeyesekere, grasping The Native's Point of View appears to have been mainly a technical problem, one that was difficult, even extremely difficult, but not much more than that. However, some anthropologists were beginning to do work that posed more radical challenges to the idea of grasping that Point of View, which reverberated with the postmodern- 
ist challenge to anthropological authority. One early sign of this was the appearance of books that presented autobiographies of local people, who have, by definition, an insider's knowledge (e.g., Keesing 1978; Shostak 1981; A. Strathern 1979). Such autobiographies pointed to what increasingly seemed to be a flaw in Geertz's view of anthropology as the interpretation of cultures, a flaw that made the idea of The Native's Point of View more problematic than it had been previously.

To see the nature of this, I return to Malinowski's Argonauts. He describes the preparation and execution of a kula voyage in terms of a typical, or perhaps archetypal, Trobriander and voyage. He wrote, that is, of The Trobriander writ large, and generally ignored the contingencies and variations of different islanders and their activities. Geertz's description of the Balinese cockfight is similar, and a fairly undifferentiated invocation of "the Balinese" recurs throughout his essay. Both Malinowski and Geertz, then, presented summary descriptions of the practices and culture of a set of people.

Those autobiographies, however, raised a question about that summary approach. To confront, say, the self-account of Ongka (A. Strathern 1979), a big man in the highlands of Papua New Guinea, is to confront an individual life, and however much such a life might be taken to illustrate Ongka's society and culture, it is still individual. That is, it points to the contingencies and variations that were lost to view when Malinowski and Geertz produced their summary descriptions of kula and cockfight, and those contingencies and variations became especially significant when postmodernist challenges to the idea of society and culture emerged in the discipline. Malinowski and Geertz might argue that the anthropologist's job is to reduce the "blooming, buzzing confusion" (James 1890: 462) observed in the field to a comprehensible summary. However, that argument rests on two assumptions, both challenged by the postmodernist critics. Firstly, it assumes that the anthropologist is competent to do the job, which is another way of saying that it assumes disciplinary authority. Secondly, it assumes that there is something like social or cultural order and regularity. I shall deal with these in turn.

The challenge to disciplinary authority appears to have echoed the increasing concern in the discipline and elsewhere with identity and its correlates. That challenge took on a political air, in the broad sense, which is understandable in light of the political structures in which social research is commonly embedded. I have already mentioned the debates about the relative positions of insiders and outsiders in relation to what became Black studies in the United States, an area in which politics in that broad sense is clearly important. In anthropology, Said's Orientalism and the work of the subaltern studies school also pointed out the political dimension of Western knowledge about alien people, those classed as Others.

This challenge undercut the anthropological endeavor, whether as conceived by Geertz or by Radcliffe-Brown. In political terms, it amounted to an assertion of parity between Anthropologist and Other, but parity of a particular sort: the assertion that the distance between Anthropologist and Other is so great that the Anthropologist cannot bridge it analytically, rather than aesthetically, as Geertz advocated, or experientially, as Viveiros de Castro urged. One form that assertion of distance took was attacks on the Western episteme, Modernist metanarratives, metropolitan perspectives, of which anthropology is a part. So, for instance, Dipesh Chakrabarty (2000: chap. 3) dismissed Gyan Prakash's (1990) approach to the ways that bonded laborers in Bihar, in colonial India, dealt with the spirit world. Prakash had related those dealings to similar dealings among tin miners in Bolivia (in Taussig 1980). Chakrabarty said that this was invalid because it depended upon the concept of capitalist production, which purports to be universal but is in fact provincial, reflecting the peculiarities of Western Europe, and hence is not applicable to those Bihari laborers.

For thoroughgoing critics of this sort, the use of intellectual apparatus of any generality, the stuff of Radcliffe-Brown's comparative sociology, is debarred, for it is a political act through which anthropologists, creatures of Western 
Modernity, dominate Others. Or, in the words of Patricia Spyer (2011: 62), "[A]ny attempt to domesticate such otherness by either explaining it away or reducing it to something already known and commonsensical is eschewed." If anthropologists thought that their task was to do research in order to improve both their models and their knowledge of the world, then they were out of a job. All that was left to them was Geertz's appreciation of otherness through interpretation or Viveiros de Castro's appreciation through adoption.

As I said, however, Geertz's project itself was under threat, because it required that there be some sort of cultural order, some Balinese way of fighting with cocks. This threat was apparent in the way that the concern with The Native's Point of View increasingly was turning into a concern with The Natives' Points of View. More and more, the whole was dissolved into its constituents, first and most thoroughly by those who said that gender made a difference, that Balinese women were likely to see the cockfight differently from the way that Balinese men saw it. The pursuit of this diversity undercut the security of the notion that there is a system or a whole, and it did so in two ways.

One of those ways echoes the fate of Ortner's injunction that structure needed to be related to individuals and their lives. As I said, her injunction was, ultimately, ignored, as many anthropologists celebrated individuals' agency and abandoned interest in structure altogether. Similarly, the growing disciplinary concern with the different sorts of Natives and their different Points of View led many to a celebration of difference, rather than to a sustained concern with how those different sorts are related to each other and linked into a whole that encompasses people who live in the same place and time. In a way, this marks the revenge of the interpretation of cultures on its author. When Geertz foreswore relating cultural expressions to things outside of themselves, he foreswore the tools needed to relate the cultural expressions of one set of Natives, or even one Native, to those of others living nearby. Without such tools, his approach offered no defense against the fragmen- tation that accompanied the pursuit of diversity. The notion of a cultural whole or system falls away; his synoptic Balinese and their cockfights shatter into different Balinese with their different cockfights.

The second way that the pursuit of the diverse undercut the notion of a system or whole is more complex, and springs from the fact that the fragmentation of social wholes has only one obvious stopping place: the individual. I do not mean the individuals of the sort presented in those autobiographies, nor the individual villager-writ-large of Malinowski's Argonauts. Rather, I mean the individual as a level of analysis and focus of disciplinary concern. Those anthropologists who pursued that fragmentation to its logical stopping place came, once more, to echo neoliberalism.

The neoclassical economics that underlay neoliberalism is renowned for its impersonal equations and graphs, developed to summarize in pure form the transactions in a market. This was a project that Geertz would have approved, for it eschewed both functionalism and psychologism. Those equations and graphs made no effort to explain why people transacted as they did, or what the consequences were, for they focused only on the moment of transaction itself. Certainly, neoclassical economists assumed that those transactions reflected people's values, their "preferences" or "utility functions," but these were treated as "exogenous" to the moment of transaction and simply taken as given. When anthropologists pursued the diversity of The Natives' Points of View by attending to individuals and their mental perceptions of their everyday lives, they ended up echoing the approach of those economists.

This individualism may have helped uncover the diversity of perspectives within a set of people. However, when those who pursued it adopted Geertz's interest in meaning and indifference to cause and effect, they found it difficult to see beyond the interior processes by which individuals make sense of things in the details of their daily lives. Culture, then, comes close to individual psychology, the preferences or utility functions that those economists in- 
voked. In particular, it was difficult to see how the personal present, the focus of this approach, might be linked to things outside of that person's here and now. It was difficult to see how that present might be linked to events in the past that shaped it, and how it might induce acts that shape the future of both the individual and others.

For neoclassical economists, this difficulty was no surprise, for they embraced it explicitly as part of their method. Those impersonal equations and graphs focus on market choice, and are indifferent to where supply and demand come from before they enter the market, just as they are indifferent to the consequences of that choice once the transactors leave the market. Indeed, it is this methodical indifference that underlay Greenspan's shocked disbelief. For some anthropologists this difficulty was embraced less explicitly. Their shift toward individualism and psychologism diverted their attention from what people do, and especially from the causes of, constraints on, and consequences of that doing. However, this diversion was implicit in the tendency to treat those doings in accord with the cultural turn, as emanations from the individual that are expressions of a culture, albeit a culture now threatened with reduction to individual orientation.

As it turned out, seeing people's thoughts and actions as expressions commonly meant ignoring that they are also communications. This meant ignoring the fact that, as communications, they link the expressing individual with others, and so can affect those others. This, in turn, meant that those anthropologists were less likely to try to figure out what those effects are and how they come about. The result threatens to resemble what, I said, Geertz seems to have pursued, Weber's rendering of the Protestant ethic, but without his attention to its social and economic consequences.

\section{Conclusion}

A lot went on in the decades that led up to the crisis, both in anthropological thought and in the discipline's institutional context, that contributed to the current air of uncertainty and introspection (Carrier forthcoming). As a result, that uncertainty and introspection have taken different forms for different members of the discipline. Rather than seeking to be comprehensive, my tale of those decades has been partial. Institutionally, I have concentrated on the audit culture and aspects of the economic crisis that have affected higher education generally, though as these are likely to be fairly familiar I have dealt with them only briefly. Intellectually, I have been concerned with what underlay the sense of intellectual exhaustion that led Marcus to say that the discipline is in suspension. Furthermore, I have argued that these two things are linked, being two faces of neoliberalism and its inadequacies.

I have sketched some of the reasons why these two faces of neoliberalism were attractive and became influential, particularly in what many saw as the failure of older orientations in the 1970s. Those concerned with economy were told that Keynesian macroeconomics was shown to be a failure because it could not deal with the stagflation that began around 1973 . Those concerned with anthropology were told that Lévi-Straussian and Marxist orientations, much less structural functionalism and Benedict's Boasian cultural anthropology, were shown to be failures because they could not deal with the tensions and changes following the end of the old colonial empires and the rise of movements like civil rights and feminism.

Neoclassical economics and postmodern anthropology were not, as I have described, just new and improved models of what had gone before. Rather, the change was radical. Economists were told that there is no economic system of the sort that the Keynesians were used to; there is only a mass of individual economic transactions and transactors. Anthropologists were told that there is no society or culture; there is only what increasingly came to look like a mass of individual human acts and actors.

In their strongest form, those challenges left members of the two disciplines with no place to stand, no perspective on the world that they 
could use to understand, explain, and assess what they studied (an instance of this loss is described in Carrier and Heyman [1997: 355356]). Many of those in economics and anthropology responded by celebrating what they had ceased to try to comprehend. For economists, that celebration took the form of arguments for market efficiency and rationality, and of efforts to see market behavior everywhere. For anthropologists, that celebration took the form of arguments for cultural diversity and human agency, and efforts to see signs of them everywhere.

Those who occupied what I have called the commanding heights in anthropology, then, foreswore the systematic use of research to extend and improve our discipline's knowledge of the world and the models by which it made sense of that world. Instead, they sought to record different people's cultural understandings and expressions. The result threatens to turn anthropology into something like the cabinet of curiosities that Nicholas Thomas (1991: chap. 4) described. Those cabinets were popular among early English travelers in the Pacific, who used them to display the curious things that they had collected during their journeys. If the discipline is reduced to this, our only legitimate intellectual activity, the sort of thing that Geertz described in his discussion of ethnographic method, is taxonomy, what Edmund Leach (1961: 2-3) dismissed as "butterfly collecting." This is a risky place for a discipline to be, as Marcus's unhappy comments about anthropology attest.

Having foresworn the critical perspective that comes from a place on which to stand, having abandoned the notion of an economic system and embraced the celebration of markets, neoclassical economists were reduced to Greenspan's shocked disbelief by the economic crisis of 2008. Anthropologists who foreswore a critical perspective and abandoned the notions of society and culture have not suffered so grievously, though when confronted with rising nationalism in Europe and the United States they have considered that, perhaps, not all diversity is good, especially (and paradoxically) if it hinders diversity.
Both of these failures appear to reflect the same neoliberal individualism: the failure to consider that people's actions can constrain or facilitate other people in ways that those involved may neither intend nor comprehend, and that those actions and their consequences might, over the course of time, form regularities and patterns that could be an Economy, Society, or Culture. The common neoclassical economic focus on individuals' rational self-interest and the market transactions that are taken to reflect it, like the common anthropological focus on individuals' cultural understandings and the agency that is taken to reflect them, ignore the larger systems of which these people, thoughts, and actions are a part.

James G. Carrier has carried out research and taught in Papua New Guinea, the United States, and the United Kingdom. His pertinent publications include Gifts and Commodities (1995), Occidentalism (ed., 1995), Meanings of the Market (ed., 1997), and The Handbook of Sociocultural Anthropology (ed. with D. Gewertz, forthcoming). He is a research associate in anthropology at Oxford Brookes University, adjunct professor of anthropology at the University of Indiana, and associate at the Max Planck Institute for Social Anthropology.

E-mail: jgc@jgcarrier.demon.co.uk

\section{References}

Alexander, Jeffrey. 1982. Positivism, presuppositions, and current controversies. London: Routledge \& Kegan Paul.

Althusser, Louis, and Étienne Balibar. 1970. Reading Capital. London: New Left Books.

Andrews, Edmund L. 2008. Greenspan concedes error on regulation. New York Times. 24 October: B1.

Asad, Talal, ed. 1973. Anthropology and the colonial encounter. London: Ithaca Press.

Benedict, Ruth. 1934. Patterns of culture. New York: Houghton Mifflin.

Boffey, Daniel. 2011. Which? magazine to test value of degrees. Guardian. 22 October, www.guardian 
.co.uk/education/2011/oct/22/which-magazinevalue-degrees.

Bourdieu, Pierre. 1977. Outline of a theory of practice. Cambridge: Cambridge University Press.

Bourdieu, Pierre. 1980. Le mort saisit le vif. Actes de la recherche en sciences sociales 32-33: 3-14.

Carrier, James G. 1997. Introduction. In James G. Carrier, ed., Meanings of the market, pp. 1-67. Oxford: Berg.

Carrier, James G. Forthcoming. Introduction. In James G. Carrier and Deborah B. Gewertz, eds., A handbook of sociocultural anthropology. London: Berg.

Carrier, James G., and Josiah Heyman. 1997. Consumption and political economy. Journal of the Royal Anthropological Institute 2: 355-373.

Chakrabarty, Dipesh. 2000. Provincializing Europe. Princeton, NJ: Princeton University Press.

Clifford, James, and George E. Marcus, eds. 1986. Writing culture. Berkeley: University of California Press.

Durkheim, Emile. [1893] 1984. The division of labour in society. London: Routledge \& Kegan Paul.

Evans-Pritchard, Edward Evans. 1940. The Nuer. Oxford: Clarendon Press.

Fabian, Johannes. 1983. Time and the other: How anthropology makes its object. New York: Columbia University Press.

Fox, Justin. 2009. Myth of the rational market. New York: Harper Business.

Fukuyama, Francis. 1992. The end of history and the last man. New York: Free Press.

Geertz, Clifford. 1973. The interpretation of cultures. New York: Basic Books.

Geertz, Clifford. 1974. "From the native's point of view": On the nature of anthropological understanding. Bulletin of the American Academy of Arts and Sciences 28: 26-45.

Gewertz, Deborah B., and Edward Schieffelin, eds. 1985. History and ethnohistory in Papua New Guinea. Oceania Monographs 28. Sydney: University of Sydney.

Guha, Ranajit, ed. 1982. Subaltern studies. Delhi: Oxford University Press.

Gupta, Akhil, and James Ferguson, eds. 1997. Culture, power, place. Durham, NC: Duke University Press.

Harvey, David. 2005. A brief history of neoliberalism. New York: Oxford University Press.
Hayek, Frederich A. 1944. The road to serfdom. London: Routledge.

James, William. 1890. The principles of psychology. New York: H. Holt and Company.

Jebens, Holger, and Karl-Heinz Kohl, eds. 2011. The end of anthropology? Wantage, UK: Sean Kingston Publishing.

Keesing, Roger, ed. 1978. 'Elota's story. St. Lucia, Australia: University of Queensland Press.

Leach, Edmund. 1961. Rethinking anthropology. London: Athlone Press.

Malinowski, Bronislaw. 1921. The primitive economics of Trobriand Islanders. Economic Journal 31(121): 1-16.

Malinowski, Bronislaw. 1922. Argonauts of the Western Pacific. London: Routledge.

Marcus, George E. 2008. The end(s) of ethnography: Social/cultural anthropology's signature form of producing knowledge in transition. Cultural Anthropology 23: 1-14.

Merton, Robert. 1972. Insiders and outsiders: A chapter in the sociology of knowledge. American Journal of Sociology 78(1): 9-47.

Mintz, Sidney W. 1985. Sweetness and power. New York: Viking.

Neumann, Klaus. 1989. Not the way it really was: Writing a history of the Tolai (Papua New Guinea). Journal of Pacific History 24: 209-20.

Obeyesekere, Gananath. 1992. The apotheosis of Captain Cook. Princeton, NJ: Princeton University Press.

Ortner, Sherry. 1984. Theory in anthropology since the sixties. Comparative Studies in Society and History 26: 126-166.

Prakash, Gyan. 1990. Bonded histories: Genealogies of labor servitude in colonial India. Cambridge: Cambridge University Press.

Radcliffe-Brown, Arthur R. 1952. Structure and function in primitive society. London: Routledge \& Kegan Paul.

Roseberry, William. 1997. Afterword. In James G. Carrier, ed., Meanings of the market, pp. 251260. Oxford: Berg.

Sahlins, Marshall. 1985. Islands of history. Chicago: University of Chicago Press.

Sahlins, Marshall. 1995. How "natives" think: about Captain Cook, for example. Chicago: University of Chicago Press.

Said, Edward. 1978. Orientalism. Harmondsworth, UK: Penguin. 
Science Watch. 2011. Sci-Bytes: Top 20 journals in anthropology, 2001-2011, ranked by citation impact. New York: Thomson Reuters. http:// sciencewatch.com/dr/sci/11/jun12-11_1D/.

Shostak, Marjorie. 1981. Nisa: The life and words of a!Kung woman. Cambridge, MA: Harvard University Press.

Spyer, Patricia. 2011. What ends with the end of anthropology? In Holger Jebens and Karl-Heinz Kohl, eds., The end of anthropology? pp. 61-80. Wantage, UK: Sean Kingston Publishing.

Strathern, Andrew. 1979. Ongka: A self-account by a New Guinea big-man. Trans. Andrew Strathern. London: Duckworth.

Strathern, Marilyn. 1988. The gender of the gift. Berkeley: University of California Press.

Strathern, Marilyn, ed. 2000. Audit cultures. London: Routledge.

Taussig, Michael. 1977. The genesis of capitalism amongst a South American peasantry: Devil's labor and the baptism of money. Comparative Studies in Society and History 19: 130-155.
Taussig, Michael. 1980. The devil and commodity fetishism in South America. Chapel Hill: University of North Carolina Press.

Thomas, Nicholas. 1991. Entangled objects. Cambridge, MA: Harvard University Press.

Viveiros de Castro, Eduardo. 2003. And. Manchester Papers in Social Anthropology 7. Manchester: Department of Social Anthropology, University of Manchester. http://nansi .abaetenet.net/abaetextos/anthropology-andscience-e-viveiros-de-castro.

Weber, Max. [1904-1905] 1958. The Protestant ethic and the spirit of capitalism. New York: Charles Scribner's Sons.

Wolf, Eric R. 1982. Europe and the people without history. Berkeley: University of California Press.

Wrong, Dennis H. 1962. The over-socialized conception of man in modern sociology. American Sociological Review 26: 183-193. 